\title{
Cellular RNA Homologous to the Abelson Murine Leukemia Virus Transforming Gene: Expression and Relationship to the Viral Sequence
}

\author{
JEAN YIN JEN WANG AND DAVID BALTIMORE* \\ The Whitehead Institute for Biomedical Research, and Center for Cancer Research and Department of Biology, \\ Massachusetts Institute of Technology, Cambridge, Massachusetts 02139
}

Received 15 November 1982/Accepted 27 January 1983

\begin{abstract}
To examine the expression of the cellular homolog of the Abelson murine leukemia virus transforming gene (the $\mathrm{v}-a b l$ sequence), a DNA probe representing the v-abl sequence was prepared. The probe detected two cytoplasmic polyadenylic acid-containing c-abl RNAs of about 6.5 and 5.5 kilobases in a variety of rodent cells, and slightly larger RNAs were detected in human cells. These two RNA species were found in all normal tissues or cell lines examined, but at differing concentrations: liver cells had the least, fibroblastic cell lines had the most. By using a probe able to detect the cellular but not the viral gene, the two RNAs were shown to be present in Abelson murine leukemia virus-transformed cells at levels found either in their untransformed counterparts or in similar cell types transformed by other means. The target cells of the virus have a somewhat elevated level of the two RNAs although expression of the c-abl gene is not restricted to these cells. The v- $a b l$ sequence lacks 0.35 and 0.85 kilobases of the c$a b l$ RNA on the 5' and 3' ends, respectively. Thus, the Abelson murine leukemia virus transforming gene is an internal fragment of the transcript of a normal cellular gene.
\end{abstract}

Abelson murine leukemia virus (A-MuLV) has a hybrid genome composed of Moloney MuLV (M-MuLV) terminal sequences surrounding an internal sequence (v-abl) derived from a region of the normal mouse DNA (c-abl) $(8,17)$. The virus is similar in structure to many other transforming retroviruses (18). The v-abl sequence is linked in phase to the gag gene of MMuLV, with terminal viral sequences providing the necessary signals for a high-level expression of the $g a g / v-a b l$ fusion protein. The fusion protein is the only protein product of the A-MuLV genome and is responsible for the transforming activity of the virus (21).

The c-abl sequence homologous to the 4.3kilobase (kb) v-abl is distributed along $30 \mathrm{~kb}$ of mouse DNA as what appears to be a series of short exons separated by long introns $(8 ; \mathrm{J}$. Y. J. Wang, S. P. Goff, F. Ledley, Y. Groner, and D. Baltimore, manuscript in preparation). That the c-abl sequence represents exons is supported by the findings of polyadenylic acid [poly(A)]-containing RNA homologous to $\mathrm{v}-a b l$ in various mammalian cells. Studies of the expression of c$a b l$ RNA during murine embryogenesis (11) or in human tumors $(6,13)$ have been reported. We prepared a full-length v-abl probe and used it to examine c-abl RNA in mouse tissues and cell lines with an emphasis on lymphoid cells. The expression of c-abl RNA in A-MuLV-transformed cells was also examined. In addition, we have analyzed the structural relationship between the v- $a b l$ sequence and c-abl RNA.

\section{MATERIALS AND METHODS}

Construction of pAB1sub9 probe. The plasmid pAB1 (Fig. 1) was digested with $K p n 1$ which cut the plasmid at a unique site in the long terminal repeated portion of the viral genome. The linearized molecule was treated with a predetermined amount of Bal 31 nuclease and was then blunt-end ligated. Escherichia coli HB101 was transformed with the total ligated DNA, and the ampicillin-resistant colonies were hybridized with an M-MuLV DNA probe. Plasmid DNA was prepared from colonies that did not hybridize to the M-MuLV probe. From these plasmids, pAB1sub9 was chosen because of its restriction enzyme digestion pattern and because it hybridized well to A-MuLV DNA but poorly to M-MuLV DNA. The presence of a small amount of homology to M-MuLV ensured that this plasmid retained the complete $5^{\prime}$ end of the $v$-abl sequence. Its content of $\mathrm{M}-\mathrm{MuLV}$ sequence was so short that it reacted with total cellular RNA and genomic DNA as a v-abl-specific probe.

Preparation of cellular RNA. Total cellular RNA was prepared from an $8 \mathrm{M}$ guanidine-hydrochloride lysate of cells by repeated precipitation with $33 \%$ ethanol, as described by Deeley et al. (5). Cytoplasmic RNA was isolated by lysing the cells in buffer containing $10 \mathrm{mM}$ $\mathrm{NaCl}, 10 \mathrm{mM}$ Tris-hydrochloride ( $\mathrm{pH} 7.4), 10 \mathrm{mM}$ 


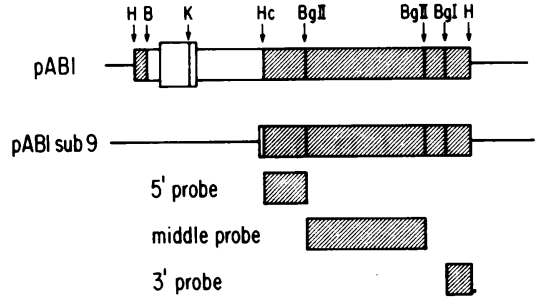

FIG. 1. v-abl probes used for the detection of homologous cellular RNA. Plasmid pAB1 is a permuted clone of the A-MuLV genome (8). Plasmid pAB1sub9 was derived from $\mathrm{pAB} 1$ as described in the text. The $5^{\prime}$ probe, middle probe, and $3^{\prime}$ probe were fragments released by restriction enzyme digestion of pAB1sub9 and were prepared by preparative gel electrophoresis. The clear area represents sequences derived from $M$ MuLV, the cross-hatched area represents the AMuLV specific sequences, and the thin line represents pBR322 sequences. Restriction enzymes: $\mathrm{H}$, HindIII; B, BamHI; K, KpnI; Hc, HincII; BgI, BglI; BgII, BglII.

$\mathrm{MgCl}_{2}, 0.5 \%$ Nonidet $\mathrm{P}-40,0.5 \%$ deoxycholate, $500 \mu \mathrm{g}$ of heparin per $\mathrm{ml}$, and $500 \mu \mathrm{g}$ of spermidine per $\mathrm{ml}$. After 10 strokes with a Dounce homogenizer, nuclei were removed by centrifugation, and RNA was precipitated with $66 \%$ ethanol. The pellet was then dissolved in the $8 \mathrm{M}$ guanidine-hydrochloride buffer, and repeated precipitation with $33 \%$ ethanol was carried out.

After the final $33 \%$ ethanol precipitation step, the RNA pellet was dissolved in $20 \mathrm{mM}$ EDTA ( $\mathrm{pH} 7.4$ ) and extracted three times with chloroform-isobutanol (4:1). The extracted RNA was dissolved in $10 \mathrm{mM}$ Tris-hydrochloride ( $\mathrm{pH} 7.4$ ) $-0.5 \%$ sodium dodecyl sulfate-1 mM EDTA plus $400 \mathrm{mM} \mathrm{NaCl}$ at a concentration so that the absorbance at $260 \mathrm{~nm}$ of the solution was 10. Poly(A)-containing RNA was then selected by chromatography on oligodeoxythymidylic acid-cellulose. Those RNAs that were bound to oligodeoxythymidylic acid-cellulose at $400 \mathrm{mM} \mathrm{NaCl}$ and eluted with the same buffer minus $\mathrm{NaCl}$ were used in the hybridization experiments.

RNA hybridizations. Poly(A)-containing RNA was denatured in $10 \mathrm{mM}$ methylmercury and applied to a $1 \%$ agarose gel in $5 \mathrm{mM}$ methylmercury-containing $\mathrm{E}$ buffer ( $50 \mathrm{mM}$ boric acid, $5 \mathrm{mM} \mathrm{Na}_{2} \mathrm{~B}_{4} \mathrm{O}_{7} \cdot 10 \mathrm{H}_{2} \mathrm{O}, 10$ $\mathrm{mM}$ sodium sulfate, $1 \mathrm{mM}$ EDTA [pH 8.2]). After electrophoresis $(100 \mathrm{~V}, 6 \mathrm{~h})$, the RNA was transferred onto diazobenzyloxymethyl-paper (DBM-paper) as described (2).

The DBM-paper was hybridized with ${ }^{32} \mathrm{P}$-labeled probes $\left(2 \times 10^{8}\right.$ to $\left.6 \times 10^{8} \mathrm{cpm} / \mu \mathrm{g}\right)$ by using dextran sulfate according to the method of Wahl et al. (19). To reuse the blot, labeled probe was washed off in $99 \%$ formamide- $0.1 \%$ sodium dodecyl sulfate at $65^{\circ} \mathrm{C}$.

Quantitative dot-blot hybridization. A given quantity of poly(A)-containing RNA in $1 \mu$ l was mixed with $1 \mu$ l of $100 \mathrm{mM} \mathrm{NaOH}$ at room temperature for $2 \mathrm{~min}$ and then neutralized with $1 \mu \mathrm{l}$ of $100 \mathrm{mM} \mathrm{HCl}$. The sample was diluted to $10 \mu$ l with $0.2 \mathrm{M}$ sodium acetate $(\mathrm{pH}$ 4.5) and spotted in 2- $\mu$ l aliquots onto freshly activated DBM-paper. Hybridization with ${ }^{32} \mathrm{P}$-labeled probes was as described above. As a standard for compari- son, poly(A)-containing RNA from ANN-1 cells (an AMuLV-transformed fibroblastic line) or 2M3 cells (an A-MuLV-transformed pre-B cell line) was applied to the DBM-paper in $10 \mu$ l containing $0.1,0.05,0.02$, 0.01 , and $0.005 \mu \mathrm{g}$. As a negative control, $1 \mu \mathrm{g}$ of poliovirus RNA was used. The other RNA samples were spotted on the same sheet of paper at given amounts. The intensity of hybridization was compared with the standards, and the level of the c- $a b l$ RNA as a percentage of the A-MuLV viral RNA was determined.

Primer extension. Restriction fragments of the v- $a b l$ region were prepared and labeled at their 5 '-ends with $\left[\gamma-{ }^{32} \mathrm{P}\right]$ ATP and polynucleotide kinase. The labeled DNA fragment plus $20 \mu \mathrm{g}$ of poly(A)-containing RNA in $10 \mu$ l of water was boiled for $2 \mathrm{~min}$ and chilled immediately on dry ice. Hybridization was carried out in $80 \%$ ( $\mathrm{vol} / \mathrm{vol}$ ) formamide (deionized and recrystallized)-0.4 M NaCl-0.01 M PIPES [piperazine- $N, N^{\prime}$ bis(2-ethanesulfonic acid)-hydrochloride] ( $\mathrm{pH}$ 6.4)-2 mM EDTA at $42^{\circ} \mathrm{C}$ for $22 \mathrm{~h}$. The hybridization mixture was diluted with $200 \mu$ l of water and ethanol precipitated to remove formamide. The precipitate was dissolved in $100 \mu$ l of $50 \mathrm{mM}$ Tris-hydrochloride ( $\mathrm{pH} \mathrm{8.3),}$ $50 \mathrm{mM} \mathrm{KCl}, 10 \mathrm{mM}$ dithiothreitol, $10 \mathrm{mM} \mathrm{MgCl}_{2}, 40$ $\mu \mathrm{g}$ of actinomycin D per $\mathrm{ml}, 600 \mu \mathrm{M}$ each of dATP, dGTP, dCTP, and dTTP, and $6 \mathrm{U}$ of reverse transcriptase. After elongation of the primer for $1 \mathrm{~h}$ at $37^{\circ} \mathrm{C}$, $\mathrm{NaOH}$ was added to $0.1 \mathrm{M}$ and the RNA was hydrolyzed at $68^{\circ} \mathrm{C}$ for $10 \mathrm{~min}$. The extended DNA was precipitated in ethanol, extracted with phenol, dissolved in $1.5 \mathrm{M}$ glyoxal, and analyzed by electrophoresis through a $1.6 \%$ agarose gel.

\section{RESULTS}

c-abl RNA in mammalian cells. To examine cells for c-abl RNA, total poly(A)-containing RNA was prepared, size-fractionated by electrophoresis, transferred to derivatized paper, and hybridized to one of the variety of v-abl probes described in Fig. 1. When a probe for the whole $\mathrm{v}-a b l$ region was used (pAB1sub9), two RNA species were detected in several rodent and human cell lines (Fig. 2). The RNAs were about 6.5 and $5.5 \mathrm{~kb}$ in rodent cells and 7.0 and $6.0 \mathrm{~kb}$ in human (HeLa) cells. Both RNAs were present in L-cell cytoplasmic RNA preparation (Fig. 2, lane B), showing that the larger is not a nuclear precursor of the smaller. All of the probes described in Fig. 1 hybridized to both RNAs, and the relative intensity of the two bands was constant (data not shown). These results demonstrate that the two RNAs are closely related, and they suggest that $\mathrm{v}-a b l$ is derived from a single gene that gives rise to two different sizes of mRNA.

Distribution of c-abl RNA in various mouse cells. Twelve different types of cells have been examined for the expression of c-abl RNA. They include normal tissues and mouse cell lines. In all cases examined, c- $a b l$ RNA of 6.5 and $5.5 \mathrm{~kb}$ could be detected in approximately constant ratios, although the absolute amount of total c- 


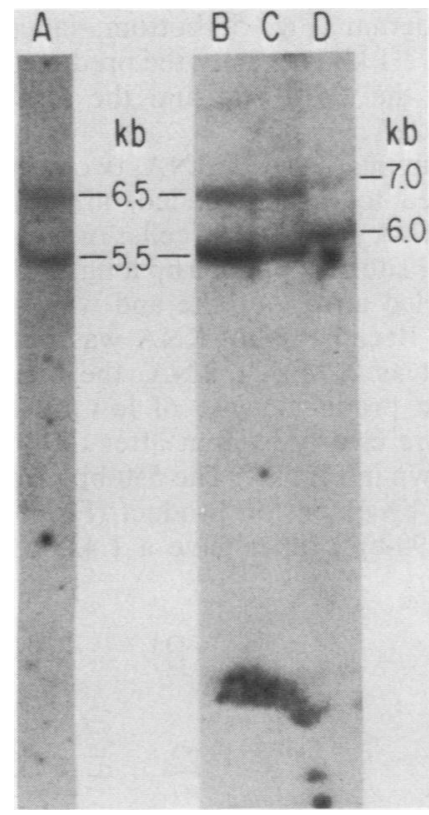

FIG. 2. c-abl RNA in mammalian cells. Poly(A)containing RNA was prepared and analyzed by hybridization to ${ }^{32} \mathrm{P}$-labeled pAB1sub9 as described in the text. Lanes: (A) $10 \mu g$ of total poly(A)-containing RNA from rat hepatoma Fao cell line; (B) $10 \mu \mathrm{g}$ of cytoplasmic poly(A)-containing RNA from mouse $L$ cells; (C) $10 \mu \mathrm{g}$ of total poly(A)-containing RNA from mouse L cells; (D) $20 \mu \mathrm{g}$ of total poly(A)-containing RNA from human HeLa cells.

$a b l$ RNA varied. The c- $a b l$ RNA content was quantitated by dot-blot hybridization by using varying amounts of RNA from A-MuLV-transformed cells as a standard for comparison (Table 1). The highest expression of c-abl RNA was found in established untransformed fibroblastic cell lines; its level there was almost $1 / 10$ that of the v-abl RNA in transformed fibroblasts. A primary fibroblast culture from BALB/c mouse embryos was also found to contain this high level of c-abl RNA. The cell density of the cultures had no apparent effect on the level of cabl RNA. Among lymphoid cells, normal thymocytes and a pre-B lymphoma line $(70 \mathrm{Z} / 3)$ were the highest producers of c-abl RNA, and a radiation-induced thymoma cell line, L691, had half the amount of c-abl RNA of normal thymocytes. Normal splenocytes from 5-week-old mice had sixfold less c-abl RNA than thymocytes from the same animals. In neonatal spleen, however, the level of c- $a b l$ RNA was comparable to that of thymocytes (11). It is not known how the c-abl RNA is distributed among the different cells making up thymocyte and splenocyte populations. Normal liver had the least amount of c-abl RNA, although a rat hepatoma cell line contained about fourfold more (Table 1).
Retroviral RNA is usually present as $1 \%$ of the total polyadenylated RNA (7). Because the level of c-abl RNA in fibroblasts, thymocytes, and a pre-B lymphoma was about 4 to $7 \%$ that of the viral RNA in an A-MuLV transformant (Table 1), the level of c-abl RNA in these cells is approximately $0.05 \%$ of the total poly(A)-containing RNA. The level of $c-a b l$ expression as a percentage of the total poly(A)-containing RNA in 13 samples is summarized in Table 1.

Expression of c-abl RNA in A-MuLV-transformed cells. A-MuLV transforms fibroblasts and pre-B lymphocytes in vitro $(15,16)$. Because both fibroblasts and a pre-B lymphoma line had relatively high levels of $c-a b l$ RNA, we examined whether c- $a b l$ RNA could be detected in AMuLV-transformed fibroblasts and pre-B cells. A-MuLV RNA is of similar size as, and it is at least 10-fold more abundant than, the endogenous RNA, so that the $v-a b l$ probes used in earlier experiments could not be used to detect c-abl RNA in A-MuLV-transformed cells. A solution to this problem became available when the genome of another A-MuLV variant, AMuLV(P160), was molecularly cloned (10). The A-MuLV(P160) genome contains 800 base pairs (bp) more sequence than the A-MuLV(P120) genome, which was used to prepare the

TABLE 1. Levels of c-abl RNA in mouse cells

\begin{tabular}{|c|c|c|c|}
\hline Cell line & Cell type & $\begin{array}{c}\mathrm{c}-a b l \\
\text { as \% } \\
\text { of } \\
\mathrm{v}-a b l^{a}\end{array}$ & $\begin{array}{c}\text { c-abl as } \\
\text { \% total } \\
\text { poly(A)- } \\
\text { RNA }\end{array}$ \\
\hline NIH 3T3 & Fibroblasts & 7.0 & 0.07 \\
\hline BALB/3T3 & Fibroblasts & 7.0 & 0.07 \\
\hline \multirow[t]{2}{*}{$\mathrm{L}$ cells } & Fibroblasts & 4.0 & 0.04 \\
\hline & $\begin{array}{l}\text { Normal thymocytes } \\
\text { (5-week-old mice) }\end{array}$ & 5.0 & 0.05 \\
\hline L691 & $\begin{array}{l}\text { Radiation-induced } \\
\text { thymoma }\end{array}$ & 2.0 & 0.02 \\
\hline $70 Z / 3$ & $\begin{array}{l}\text { Chemically induced } \\
\text { pre-B lymphoma }\end{array}$ & 4.0 & 0.04 \\
\hline MOPC-11 & Myeloma & 2.0 & 0.02 \\
\hline MOPC-104E & Myeloma & 1.0 & 0.01 \\
\hline WEHI231 & $\begin{array}{l}\text { Chemically induced } \\
\text { B-cell lymphoma }\end{array}$ & 1.4 & 0.014 \\
\hline \multirow[t]{3}{*}{$745 P C 4$} & $\begin{array}{l}\text { Friend virus-induced } \\
\text { erythroblastoid }\end{array}$ & 2.0 & 0.02 \\
\hline & $\begin{array}{l}\text { Normal splenocytes } \\
\text { (5-week-old mice) }\end{array}$ & 0.8 & 0.008 \\
\hline & Liver & 0.4 & 0.004 \\
\hline Fao & Hepatoma (rat) & 1.5 & 0.015 \\
\hline
\end{tabular}

${ }^{a}$ Comparison of hybridization intensity between RNA samples containing c-abl RNA and those containing v-abl RNA on a dot-blot is described in the text. For example, $1.5 \mu \mathrm{g}$ of poly(A)-containing RNA from NIH 3T3 fibroblasts gave the same intensity as $0.1 \mu \mathrm{g}$ of poly(A)-containing RNA from ANN-1 or 2M3 cells. Thus, the c-abl RNA is $1 / 15$ of the $v-a b l$ R.NA, about $7 \%$. 


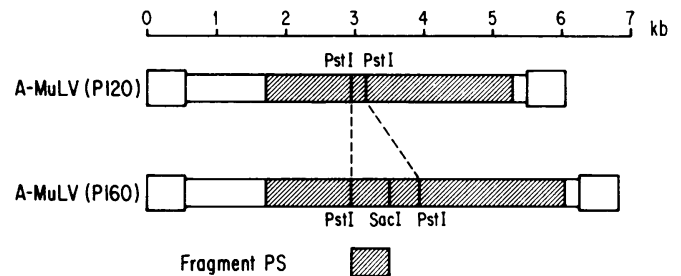

FIG. 3. DNA probe used for the detection of c-abl RNA in A-MuLV-transformed cells. The genome of $A-M u L V(P 160)$ is larger than that of A-MuLV(P120) by 800 bp located within the PstI restriction fragment indicated in the Figure. Within the 800 -bp sequence is a single SacI site. The indicated restriction fragment PS of 550 bp was chosen because it did not hybridize to A-MuLV(P120) DNA but did hybridize to $c-a b l$ RNA.

pAB1sub9 probe. [A-MuLV(P120) is actually a deletion mutant of A-MuLV(P160).] As shown in Fig. 3, this 800-bp extra segment is located in a PstI fragment in the v-abl region. A PstI to $S a c I$ fragment (PS) derived from this region was found to be specific to the A-MuLV(P160) genome in that it did not hybridize to AMuLV(P120) DNA. Therefore, fragment PS could be used to detect c-abl RNA in cells transformed by the A-MuLV(P120) variant. When the pAB1sub9 and PS probes were hybridized to RNA from NIH 3 T3 or $70 Z / 3$ cells, both probes detected the same c-abl RNAs (Fig. 4, lanes 1 and 2). When RNA from AMuLV(P120)-transformed lymphoid cells was hybridized with these probes, pAB1sub9 gave rise to the 5.5-kb viral RNA band (Fig. 4A, lanes 3, 4 and 6), but fragment PS detected the two c$a b l$ RNAs (Fig. 4B, lanes 3, 4, and 6). An RNA sample from line 22D6, an A-MuLV(P160)transformed line, was also included in the experiment to show that both probes hybridized to the 6.3-kb viral RNA of A-MuLV(P160) (Fig. 4, lanes 5). In fibroblasts transformed by AMuLV(P120), the two c-abl RNAs were also detected. Thus, expression of the A-MuLV genome does not repress the synthesis of c-abl RNA.

Relationship between c-abl RNA and v-abl sequence. Because c- $a b l$ RNA is larger than the v$a b l$ sequence, we examined whether the ends of the $\mathrm{c}-a b l$ sequence were deleted during the formation of the A-MuLV genome by primer extension experiments. Three different restriction fragments from the $5^{\prime}$ portion of the v-abl sequence were used as primers for reverse transcriptase (Fig. 5). As a positive control, the primer labeled at the $B g$ III site was hybridized to poly(A)-containing RNA from the A-MuLVtransformed cell line, ANN-1. The longest reverse-transcription product was $2.1 \mathrm{~kb}$, as evidenced by two different exposures of the autoradiogram (Fig. 5, bottom, lanes 1). The length of $2.1 \mathrm{~kb}$ is exactly the predicted distance between the $\mathrm{Bg} / \mathrm{II}$ site and the $5^{\prime}$ end of AMuLV RNA.

To examine the c-abl RNA, two primers were hybridized to, and extended on, poly(A)-containing RNA of mouse L cells: one was labeled at a $S m a$ I site and was $550 \mathrm{bp}$ long, and the other was labeled at a $S a c I$ site and was 90 bp long (Fig. 5). Because c- $a b l$ RNA was only $1 / 10$ as abundant as A-MuLV RNA, the bands of the extension products were of low intensity and were more clearly evident after the long exposure shown in Fig. 5B. The 550-bp primer yielded a 900-bp extension product (Fig. 5, lane 2), and the 90 -bp primer gave a 1,425 -bp product

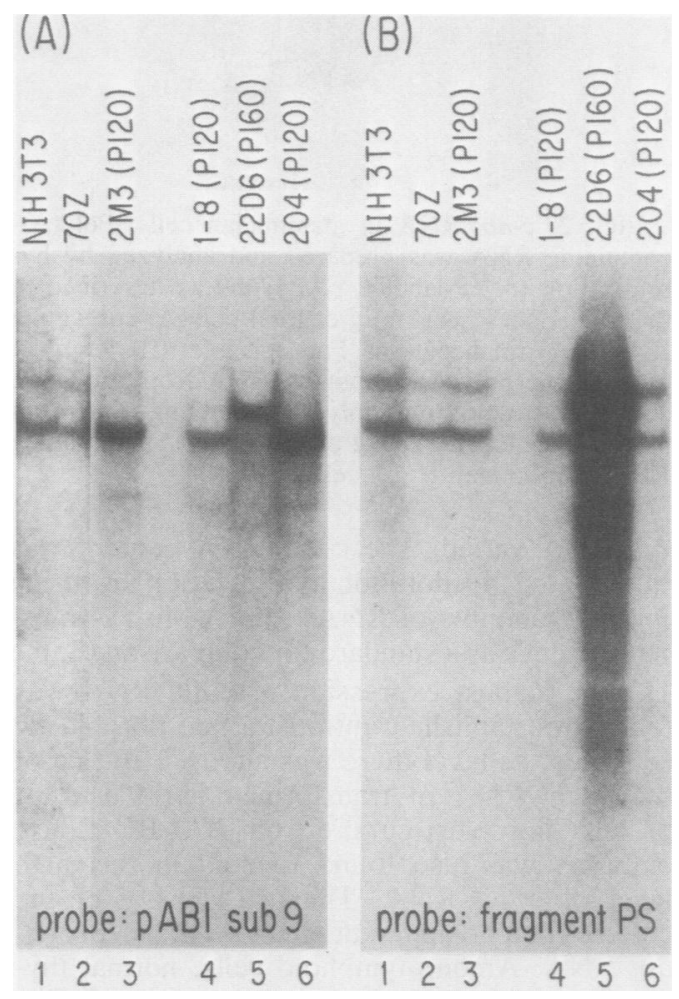

FIG. 4. A-MuLV-transformed cells contain c-abl RNA. Ten micrograms of total poly(A)-containing RNA from the following cell lines was analyzed by hybridization to ${ }^{32}$ P-labeled probes: (1) NIH 3T3, (2) $70 \mathrm{Z} / 3$, (3) $2 \mathrm{M} 3$, (4) $1-8$, (5) 22D6, (6) 204. Cell lines 2M3, 1-8, and 204 were transformed by AMuLV(P120), whereas cell line 22D6 was derived by transformation with A-MuLV(P160). The DBM-paper was first hybridized to ${ }^{32}$ P-labeled pAB1sub9 (A). After exposure of the paper to X-ray film, the labeled probe was washed off and a second hybridization with ${ }^{32}$ P-labeled fragment PS was performed (B). In (A), lanes 1 and 2 are from a longer exposure ( 2 days) and lanes 3 to 6 are from a shorter exposure $(16 \mathrm{~h})$ of the same paper. 


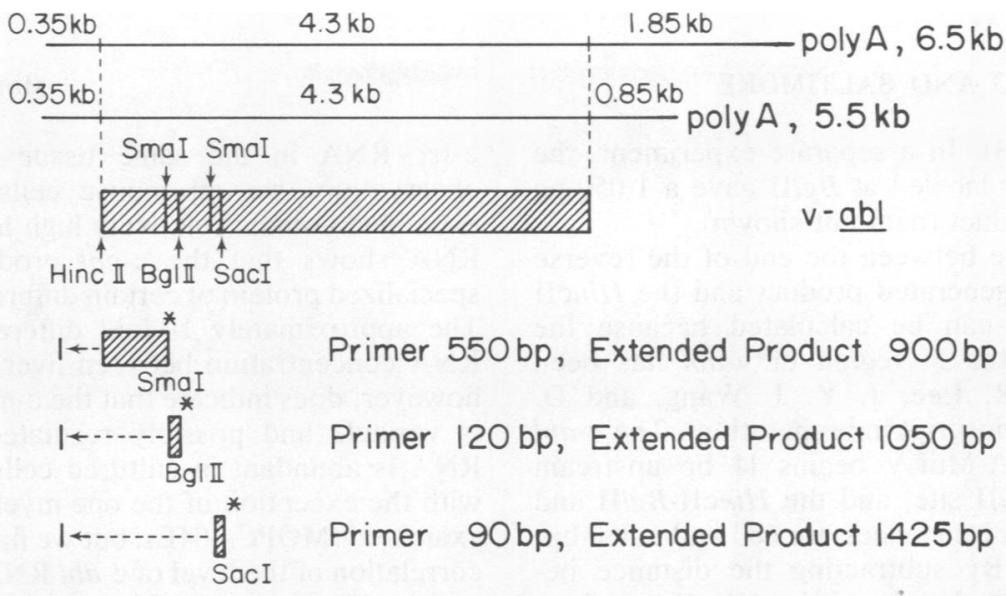

\begin{tabular}{lr} 
Fragment Size (bp) & $c-$-abl RNA 5' end to HincI (bp) \\
\cline { 2 - 2 } HincII-SmaI 550 & $900-550=350$ \\
HincII - Bgl I 680 & $1050-680=370$ \\
HincII-SacI 1080 & $1425-1080=345$
\end{tabular}

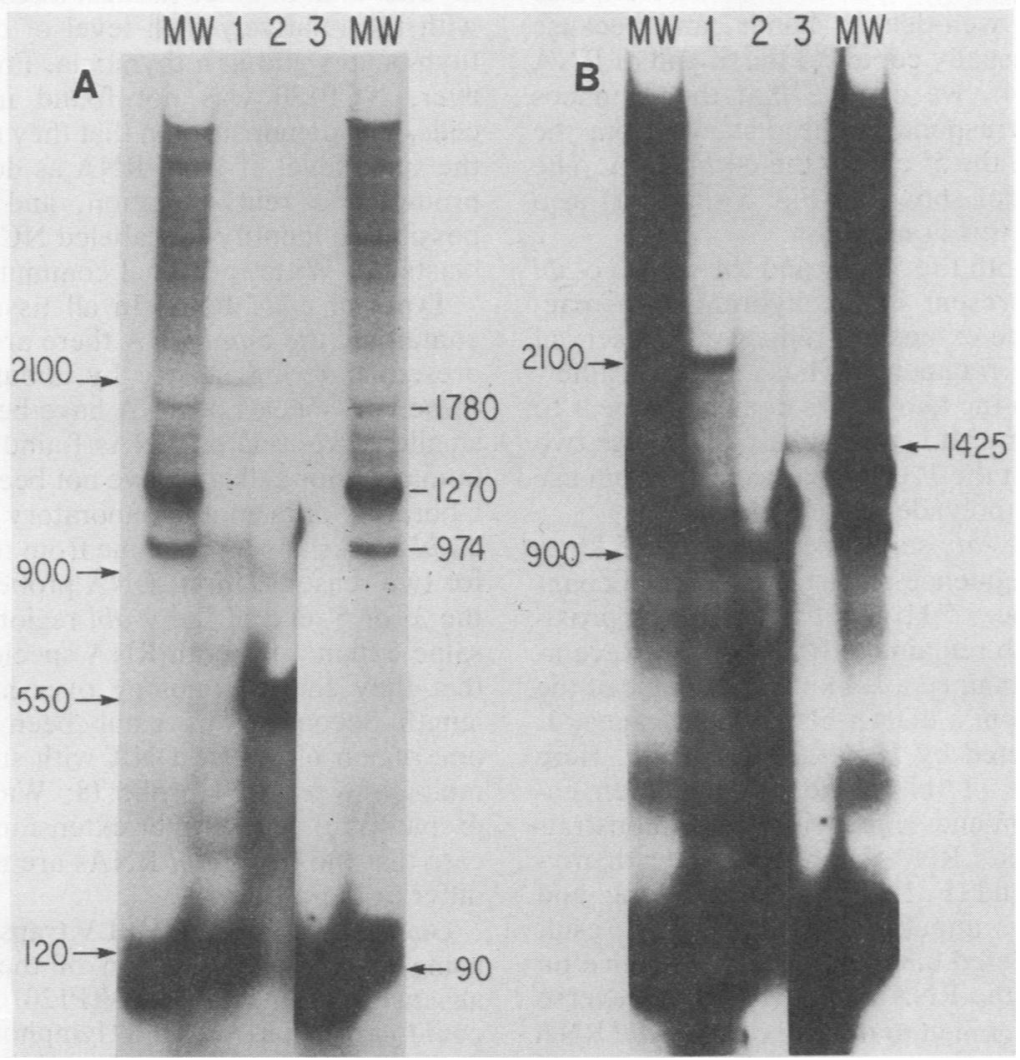

FIG. 5. Primer extension of v-abl sequences on A-MuLV and c-abl RNA. The length and positions of the three $\mathrm{v}$ - $a b l$ restriction fragments are as indicated (top). They were labeled at the $5^{\prime}$ end with ${ }^{32} \mathrm{P}$, hybridized to RNA, and extended with reverse transcriptase as described in the text. The molecular weight markers (MW) are the in vitro run-off transcripts of adenovirus promoters $(1,780,1,270$, and $974 \mathrm{bp})$ provided by Andrew Fire (M.I.T). Two different exposures of a gel are presented: exposure (A) was for $24 \mathrm{~h}$, exposure (B) was for 4 days (bottom). (Lane 1) The SmaI-BglII fragment hybridized to $10 \mu \mathrm{g}$ of poly(A)-containing RNA from A-MuLVtransformed fibroblasts, ANN-1, and extended with reverse transcriptase. (Lane 2) The HincII-SmaI fragment hybridized to $20 \mu \mathrm{g}$ of poly(A)-containing RNA from mouse L cells and extended. (Lane 3) The SmaI-SacI fragment hybridized to $20 \mu \mathrm{g}$ of poly(A)-containing RNA from mouse L cells and extended. 
(Fig. 5, lane 3). In a separate experiment, the 120-bp primer labeled at $B g / I I$ gave a 1,050 -bp extension product (data not shown).

The distance between the end of the reverse transcriptase-generated product and the HincII site in $\mathrm{v}-a b l$ can be calculated because the sequence of the $5^{\prime}$ region of $\mathrm{v}-a b l$ has been determined (R. Lee, J. Y. J. Wang, and D. Baltmore, manuscript in preparation). The v-abl sequence of $\mathrm{A}-\mathrm{MuLV}$ begins $11 \mathrm{bp}$ upstream from the HincII site, and the HincII-BgIII and the HincII-SacI distances are 680 and $1,080 \mathrm{bp}$, respectively. By subtracting the distance between the labeled end and the HincII site from the final size of the extended product, we obtained the distance between the $5^{\prime}$ end of the reverse transcriptase product and the $5^{\prime}$ end of $\mathrm{v}-a b l$. As shown in Fig. 5 (top), the three independent primer extensions gave the consistent result that the $5^{\prime}$ end of the reverse transcriptase product was about 355 bp upstream from the HincII site. Because the reverse transcriptase products are well-defined bands, and because the enzyme usually copies to the 5' end of RNA molecules (14), we assume that the distances measured correspond to the distance from the HincII site to the $5^{\prime}$ end of the c-abl RNA. The positive control shown in Fig. 5 (lanes 1) also substantiates this assumption.

Although both the $5.5-\mathrm{kb}$ and the $6.5-\mathrm{kb} \mathrm{c}-a b l$ RNA were present in the hybridization reactions, only one extended product was observed with all three fragments. Thus, the 1-kb difference between the two RNAs does not appear to be at the $5^{\prime}$ end. It is most likely that these two RNAs differ at the $3^{\prime}$ end and they arise from use of alternative polyadenylation sites.

The 4.3-kb v-abl sequence plus the $0.35-\mathrm{kb}$ c$a b l$-specific sequence at the $5^{\prime}$ end can account for $85 \%$ of the $5.5-\mathrm{kb}$ c-abl RNA, but approximately $0.85 \mathrm{~kb}$ remains to be localized. Recently, we have obtained a 1.4-kb cDNA clone of the c-abl RNA from a cDNA library from mouse $\mathrm{L}$ cells constructed by $\mathrm{H}$. Okayama and P. Berg (12). Analysis of this clone by restriction enzyme digestion and sequencing has demonstrated that the c-abl RNA is 0.85 kb longer than v$a b l$ at the $3^{\prime}$ end (F. Ledley, J. Y. J. Wang, and D. Baltimore, unpublished data). This result places the deleted $0.85 \mathrm{~kb}$ of $\mathrm{c}-a b l$ sequence on the 3' end of the RNA and verifies that reverse transcriptase copied to the end of the c-abl RNA in the primer extension experiment.

\section{DISCUSSION}

Levels of c-abl RNA. Compared to other c-onc RNAs, the levels of c-abl transcripts are, in general, higher. Even at its lowest, i.e., in the liver, the level of c-abl RNA is an order of magnitude higher than that of $\mathrm{c}-m y b, \mathrm{c}-m y c$, or c-src RNA in the same tissue $(9,11)$. The observation that all mouse cells and tissues examined contain relatively high levels of c- $a b l$ RNA shows that the c-abl product is not a specialized protein of certain differentiated cells. The approximately 10 -fold difference of c-abl RNA concentration between liver and thymus, however, does indicate that the c-abl expression is variable and possibly regulated. The c-abl RNA is abundant in cultured cells of all types with the exception of the one myeloma cell line examined (MOPC-104E), but we find no obvious correlation of the level of c-abl RNA with malignancy. The only notable regularity is in the lymphoid cell lineage, where the expression of the $c-a b l$ gene is higher in immature cells than in mature cells.

Previous studies have identified a cellular protein called NCP150 that shares antigenicity with the v-abl-encoded polypeptide sequence (20). That protein was much more abundant in thymus than in other tissues, a result consistent with the relatively high level of c-abl RNA in thymocytes and in a thymoma. Formerly, however, NCP150 was not found in fibroblastic cells. The demonstration that they contain about the same level of c-abl RNA as do thymocytes prompted a reinvestigation, and it has been possible to identify ${ }^{32} \mathrm{P}$-labeled NCP150 in fibroblasts $(\mathrm{O}$. Witte, personal communication).

Types of c-abl RNA. In all tissues and cells containing the c-abl RNA there are two species present differing in size by about $1 \mathrm{~kb}$. Only these two species of RNA have been observed; smaller c-abl-related RNAs found by others in human tumor cells (6) have not been seen in this laboratory or in another laboratory (13). The two c-abl RNAs appear to come from the same gene for two reasons. First, DNA probes specific for the $3^{\prime}$ or $5^{\prime}$ end of the $\mathrm{v}-a b l$ region react to the same extent with both RNA species, indicating that they share homology over much of their length. Second, we have only been able to detect one region of mouse DNA with substantial homology to a $\mathrm{v}-a b l$ probe $(8$; Wang et al., in preparation). The primer extension results indicate that the two c-abl RNAs are most likely to differ at their $3^{\prime}$ ends.

c-abl expression in A-MuLV transformants. By using as a probe a region of the v-abl DNA absent from the A-MuLV(P120) genome, we could show that A-MuLV lymphoid transformants contain about as much c-abl RNA as a cell line of similar phenotype transformed by other means (70Z/3 cells). A-MuLV fibroblastic transformants also have about the same level of c-abl RNA as their untransformed counterparts. Thus, expression of the A-MuLV(P120) genome neither enhances nor represses the expression of the $c-a b l$ gene. 
Assuming that the level of c-abl RNA in the A-MuLV transformant is characteristic of its level in the target cell (pre-B lymphocytes), the A-MuLV target cell would appear to have a relatively high expression of the c-abl gene. The A-MuLV transformant is probably a good model of its normal counterpart because of their similar surface antigens (3) and their immunoglobulin gene configuration (1). Other cells that have relatively high levels of c-abl RNA (thymocytes and fibroblasts) are also targets for A-MuLV transformation under certain circumstances $(4$, 16). It is possible that cells with higher expression of the c-abl gene are more susceptible to AMuLV transformation. This observed correlation between c-abl expression and A-MuLV transformation, however, does not necessarily explain the target specificity.

A-MuLV contains a fragment of the $c-a b l$ RNA. Our results show that the v- $a b l$ region of the A$\mathrm{MuLV}(\mathrm{P} 160)$ genome is an internal fragment of the c-abl RNA and that about $0.35 \mathrm{~kb}$ on the $5^{\prime}$ end and $0.85 \mathrm{~kb}$ (or $1.85 \mathrm{~kb}$ ) on the $3^{\prime}$ end of the cellular RNA were eliminated during the formation of the A-MuLV hybrid genome. Some of the c- $a b l$ RNA coding sequence on the $5^{\prime}$ end must be deleted because there is no ATG codon at the extreme $5^{\prime}$ end of $\mathrm{v}-a b l$. How much, if any, of the $3^{\prime}$ coding sequence is present in the $0.85-\mathrm{kb}$ deletion is unknown; the size of the c-abl-encoded protein $\left(M_{\mathrm{r}}=150,000\right)$ compared to that encoded by $v-a b l\left(M_{\mathrm{r}}=130,000\right)$ suggests that some c- $a b l$ coding sequence is absent from AMuLV. It is possible that the loss of c-abl coding sequence contributes to the oncogenicity of AMuLV.

\section{ACKNOWLEDGMENTS}

This work was supported by National Cancer Institute gran CA26717 and a National Cancer Institute Core Grant CA14051 (to S. E. Luria). J.Y.J.W. is a postdoctoral fellow of the Jane Coffin Childs Memorial Fund for Medical Research. D.B. is an American Cancer Society Research Professor.

\section{LITERATURE CITED}

1. Alt, F., N. Rosenberg, S. Lewis, E. Thomas, and D. Baltimore. 1981. Organization and reorganization of immunoglobulin genes in A-MuLV-transformed cells: rearrangement of heavy but not light chain genes. Cell 27:381390.

2. Alwine, J. C., D. J. Kemp, and G. R. Stark. 1980. Detection of specific RNAs or specific fragments of DNA by fractionation in gels and transfer to diazobenzyloxymethyl paper. Methods Enzymol. 68:220-242.

3. Baltimore, D., N. Rosenberg, and O. N. Witte. 1979. Transformation of immature lymphoid cells by Abelson murine leukemia virus. Immunol. Rev. 48:1-22.
4. Cook, W. 1982. Rapid thymomas induced by Abelson murine leukemia virus. Proc. Natl. Acad. Sci. U.S.A. 79:2917-2921.

5. Deeley, R. G., J. I. Gordon, A. T. H. Burns, K. P. Mullinix, M. Binastein, and R. F. Goldberg. 1977. Primary activation of the vitellogenin gene in the rooster. J. Biol. Chem. 252:8310-8319.

6. Eva, A., K. C. Robbins, P. R. Andersen, A. Srinivasan, S. R. Tronick, E. P. Reddy, N. W. Ellmore, A. T. Galen, J. A. Lautenberger, T. S. Papas, E. H. Westin, F. WongStaal, R. C. Gallo, and S. A. Aaronson. 1982. Cellular genes analogous to retroviral onc genes are transcribed in human tumour cells. Nature (London) 295:116-119.

7. Fan, H., and D. Baltimore. 1973. RNA metabolism of murine leukemia: detection of virus-specific RNA sequences in infected and uninfected cells and identification of virus-specific messenger RNA. J. Mol. Biol. 80:93-117.

8. Gof, S. P., E. Gilboa, O. N. Witte, and D. Baltimore. 1980. Structure of the Abelson murine leukemia virus genome and the homologous cellular gene: studies with cloned viral DNA. Cell 22:777-785.

9. Gonda, T. J., D. K. Sheiness, and J. M. Bishop. 1982. Transcripts from the cellular homologs of retroviral oncogenes: distribution among chicken tissues. Mol. Cell. Biol. 2:617-624.

10. Latt, S. A., S. P. Goff, C. J. Tabin, M. Paskind, J. Y. J. Wang, and D. Baltimore. 1983. Cloning and analysis of reverse transcript $\mathrm{P} 160$ genomes of Abelson murine leukemia virus. J. Virol. 45:1195-1199.

11. Muller, R., D. J. Slamon, J. M. Tremblay, M. J. Cline, and I. M. Verma. 1982. Differential expression of cellular oncogenes during pre- and post-natal development of the mouse. Nature (London) 299:640-643.

12. Okayama, H., and P. Berg. 1982. High-efficiency cloning of full-length cDNA. Mol. Cell. Biol. 2:161-170.

13. Ozanne, B., T. Weeler, J. Zack, G. Smith, and B. Dale. 1982. Transforming gene of a human leukemia cell is unrelated to the expressed tumor virus related gene of the cell. Nature (London) 299:744-746.

14. Racaniello, V. R., and D. Baltimore. 1981. Molecular cloning of poliovirus cDNA and determination of the complete nucleotide sequence of the viral genes. Proc. Natl. Acad. Sci. U.S.A. 78:4887-4891.

15. Rosenberg, N., and D. Baltimore. 1976. A quantitative assay for transformation of bone marrow cells by Abelson murine leukemia virus. J. Exp. Med. 143:1453-1463.

16. Scher, C. D., and R. Siegler. 1975. Direct transformation of $3 \mathrm{~T} 3$ cells by Abelson murine leukemia virus. Nature (London) 253:729-732.

17. Shields, A., S. P. Gof, M. Paskind, G. Otto, and D. Baltimore. 1979. Structure of the Abelson murine leukemia virus genome. Cell 18:955-962.

18. Varmus, H. E. 1982. Form and function of retroviral proviruses. Science 216:812-820.

19. Wahl, G. M., M. Stern, and G. R. Stark. 1979. Efficient transfer of large DNA fragments from agarose gels to diazobenzyloxymethyl-paper and rapid hybridization by using dextran sulfate. Proc. Natl. Acad. Sci. U.S.A. 76:3683-3687.

20. Witte, O. N., N. E. Rosenberg, and D. Baltimore. 1979. A normal cell protein cross-reactive to the major Abelson murine leukemia virus gene product. Nature (London) 281:396-398.

21. Witte, O. N., N. Rosenberg, M. Paskind, A. Shields, and D. Baltimore. 1978. Identification of an Abelson murine leukemia virus-encoded protein present in transformed fibroblasts and lymphoid cells. Proc. Natl. Acad. Sci. U.S.A. 75:2488-2492. 